\title{
Response of durum wheat (Triticum durum, L.) to different combinations of chemical nitrogen fertilizer levels and the red yeast as a biofertilizer
}

\author{
Nagib, S.R. ${ }^{1}$, M.M. Abd El-Mageed ${ }^{1 *}$ and S.A. Haddad ${ }^{2}$ \\ ${ }^{1}$ Agronomy Department, Faculty of Agriculture, Minia University. El-Minia, Egypt \\ ${ }^{2}$ Agricultural Microbiology Department, Faculty of Agriculture, Minia University. El-Minia, Egypt
}

\begin{abstract}
The aim of this research was to assess the impact of different combinations of chemical nitrogen fertilizer levels and red yeast as a biofertilizer $\left(\mathrm{F}_{1}, 100 \mathrm{~kg} \mathrm{~N}+\right.$ red yeast; $\mathrm{F}_{2}, 75 \mathrm{~kg} \mathrm{~N}+$ red yeast; $\mathrm{F}_{3}, 50 \mathrm{~kg} \mathrm{~N}+$ red yeast; $\mathrm{F}_{4}, 25 \mathrm{~kg} \mathrm{~N}+$ red yeast; $F_{5}$, unfertilized $\mathrm{N}+$ red yeast and $\mathrm{F}_{6}, 100 \mathrm{~kg} \mathrm{~N}$ without red yeast) on microbial biomass carbon and nitrogen, growth characteristics, yield and its components as well as harvest index of four durum wheat cultivars $\left(\mathrm{V}_{1}\right.$, Beniswif 5; $\mathrm{V}_{2}$, Beni-swif $1 ; \mathrm{V}_{3}$, Sohag4; $\mathrm{V}_{4}$, Sohag5). Results confirmed that, different wheat cultivars exhibited a significant effect on most studied traits in both seasons. $V_{1}$ surpassed all tested cultivars for most studied traits followed by V2, meanwhile, V4 ranked the last one for most traits in both seasons. The combination of all chemical nitrogen fertilizers with red yeast possessed a highly significant effect on all studied characteristics. Significant interactions were recorded between cultivars and different combinations of yeast and nitrogen fertilizer levels on wheat yield and its components during both seasons, $\mathrm{V}_{2} \times \mathrm{F}_{2}$ and $\mathrm{V}_{2} \times \mathrm{F}_{1}$ obtained the greatest biological yield of 7.89 and 7.40 ton/fed. and grain yield of 20.75 and 20.49 ardab/fed in the first and second seasons, respectively. Grain yield (ardab/fed.) was highly positive and significantly correlated with all studied traits in both seasons. In conclusion, applying red yeast as a promising biofertilizer with different chemical nitrogen fertilizer rates could be recommended because it significantly increased the microbial biomass and, achieved a highly significant wheat yield, while reducing chemical fertilizers consumption.
\end{abstract}

Keywords: Biofertilizers; Durum wheat; Nitrogen; Microbial biomass; Red yeast.

\section{Introduction}

Wheat is the most important cereal crop which ranks first among the cereal crops in the world, accounting for $30 \%$ of all cereal food worldwide and major food for over one third of world people that provides about $20 \%$ of the total food calories directly or indirectly for humans Namvar and Khandan (2013). In Egypt, increasing wheat production is an essential national target to fill the gap between production which reached 9 million tons and consumption which increased to 16 million tons FAO Statistics Division (2019).

\footnotetext{
*Corresponding author: Mahmoud M. Abd El-Mageed Email: mahmoud.salim@mu.edu.eg

Received: December 7, 2021; Accepted: January 19, 2022; Published online: January 28, 2022 (C) Published by South Valley University. This is an open access article licensed under c)(-)
}

At the present time, due to the highly fertile alluvial soils and availability of Nile water for irrigation, wheat productivity in Egypt is the highest in Africa (Yigezu et al., 2021). For example, the average wheat production in the country is about 6.7 tons/ha which is much higher than the African average of 2.6 tons/ha. However, due to the rapid population growth, the country is under pressure to reclaim new lands for agriculture and thus increase

the pressure on limited arable soils and water supply. Another national challenge that Egypt is currently facing is that due to the intensive chemical fertilizer application, 35\% of agricultural land suffers from pollution, salinity and, poor biodiversity which reduces the productive capacity of the fertile alluvial soils (FAO Statistics Division, 2019). Increasing the 
yield of wheat (Triticum aestivum L.) is a vital national goal to meet the growing food needs of the Egyptian population, while wheat is one of the three major cereal crops (Niel, 2021). The Egyptian government and scholars have paid great attention and efforts to increase wheat productivity to narrow the wheat security gap in production and consumption by increasing water productivity, fertilizer use efficiency, unit productivity area and, increasing the cultivated area (FAO Statistics Division, 2019; Niel, 2021; Yigezu et al., 2021).

Increasing wheat production per unit area can be achieved by breeding and cultivating the promising wheat cultivars and applying the optimum cultural practices such as suitable fertilizer. There was a significant difference among cultivars (Zaki et al., 2016; Yasser et al., 2018). Many research demonstrated that wheat cultivars differed significantly for growth, yield, and yield components (Hasanpour et al., 2012; Mohamed et al., 2013; Taher et al., 2013; Nabila et al., 2015; Bizuwork and Yibekal, 2020).

Nitrogen is one of the essential nutrients for plants and its practical management as the major element for intensive plant production is an important aspect. Many investigators reported the meliorating effect of $\mathrm{N}$-fertilizers on wheat yield and its components, No. of spikes $/ \mathrm{m}^{2}$, grain yield/fad., and harvest index (Abdul Galil et al., 2003) plant height significantly affected by $\mathrm{N}$ levels, the tallest plants $89.40 \mathrm{~cm}$ are noted in $92 \mathrm{~kg} \mathrm{~N} / \mathrm{ha}^{-1}$ (Bizuwork and Yibekal, 2020) grain number/spike, spike number/ $\mathrm{m}^{2}, 1000$ grain weight, and grain yield/fad. (Hafez, 2007); spike number/m², grain number/ spike, grain weight/spike, 1000-grain weight, and grain yield/fad. (Amin et al., 2011; Farag and ElKhawaga, 2013). The steadily increasing prices of chemical fertilizers, especially nitrogenous fertilizers, and severe negative environmental impacts on soil and water, have led to the development of alternative strategies, use of biological fertilizers today is considered to limit the use of mineral fertilizers (El-Sirafy et al., 2006). Application of biofertilizers decreases agricultural costs, maximizing crop yield due to providing them with an available nutritive elements and growth promoting substances (Metin et al., 2010). The use of bio-fertilizers could reduce amount of chemical fertilizer input by increasing the efficiency of nutrient availability and other plant growth-promoting activities. Bio-fertilizers hold a promise to balance many drawbacks of the conventional chemical-based technology and could recuperate healthy farming practices and bio-farming (Minaxi et al., 2013; Amira et al., 2016; Moustafa et al., 2017). Using of either organic or biofertilizer are considered a safe alternative for chemical fertilizers, which cause environmental pollution when they are used extensively Ozturk et al., 2012; Abd El-Lateef, 2018). Biofertilizers inoculation significantly increased most growth and yield parameters, yeast had superiority on Azotobacter. Moreover, mixed inoculums, generally, had more favorable effect on the majority of studied parameters than single inoculants (El-Sirafy et al., 2006; Bahrani and Pourreza, 2010; Nawab et al., 2006; Amal et al., 2011). Many authors achieved the positive effect of bio-fertilizer on wheat (Singh and Prasad, 2011; Amira et al., 2016; Abd El-Lateef, 2018).

Little information is available on the effect of red yeast application as a biofertilizer in combination with different application rates of inorganic nitrogen fertilizer on the productivity, growth, and grain quality characteristics of different wheat cultivars. Investigating new yeasts as biofertilizers expands our knowledge about their approached mechanisms due to their productivity of bioactive chemical compounds that improve soil quality and enhance plant growth and quality characteristics. In addition to its role in promoting plant growth and quality, yeast as a biofertilizer can act in unison as biocontrol agents in the soil rhizosphere (AbouZeed, et al., 2014). Red yeast 
(Xanthophyllomyces dendrorhous) (formerly Phaffia) is considered as a new promising plant growth-promoting yeast for different crops. Recently, it became a positive alternative to chemical fertilizers safely used for humans, animals, and the environment (Moustafa et al., 2017). Previous studies clarified the effect of yeast soil application as a biofertilizer on vegetative growth parameters owing to its affluence in tryptophan which is a precursor of IAA (Indole acetic acid) and on flower trigger because of increasing carbohydrate accumulation (Abou-Zeed, et al., 2014; Yasser et al., 2018). Moreover, significant changes in soil microbial biomass $\mathrm{C}$ and $\mathrm{N}$ have been explored from prior research studies during the cropping seasons and under different soil fertilization systems and techniques (Haddad et al., 2013). Generally, microbial biomass can be utilized for soil quality assessments in situations involving different crop genotypes and different fertilization practices (Moustafa et al., 2018). The main objectives of this study were to evaluate the influence of combined chemical nitrogen fertilizer and red yeast as a biofertilizer on microbial biomass and productivity of four durum wheat cultivars under middle Egypt conditions.

\section{Materials and methods}

\section{1. $\quad$ Soil used}

The soil of the experimental location had a clay loam texture. Preceding to the inception of the field trial, clay loam soil detailed in Table 1 was collected, air dried, sieved to $<2.0 \mathrm{~mm}$, and composite sub-samples were used to determine the basic soil physical and chemical properties according to Avery and Bascomb (1982).

Table 1. Physical and chemical properties of the experimental soil.

\begin{tabular}{|c|c|c|c|}
\hline Soil chemical properties & Value & Soil physical properties & Value \\
\hline $\mathrm{pH}(1: 2.5$ water $)$ & 7.7 & F.C. $\%$ & 42.45 \\
\hline $\mathrm{CaCO}_{3}\left(\mathrm{~g} \mathrm{~kg}^{-1}\right)$ & 17.9 & PWP \% & 13.78 \\
\hline $\operatorname{CEC~}\left(\mathrm{cmol}_{\mathrm{c}} \mathrm{kg}^{-1}\right)$ & 37.87 & WHC \% & 48.76 \\
\hline $\mathrm{EC}\left(\mathrm{dS} \mathrm{m} \mathrm{m}^{-1}\right.$ at $\left.25{ }^{0} \mathrm{C}\right)$ & 1.35 & A. V. (F.C. - PWP) \% & 28.67 \\
\hline $\mathrm{OM}\left(\mathrm{g} \mathrm{kg}^{-1}\right)$ & 28.61 & A. V. (WHC-PWP) $\%$ & 34.98 \\
\hline Total N ( $\left.\mathrm{g} \mathrm{kg}^{-1}\right)$ & 1.29 & Sand $\%$ & 28.9 \\
\hline Total $\mathrm{C} / \mathrm{N}$ ratio & 22.17 & Silt $\%$ & 32.8 \\
\hline $\operatorname{SOC}\left(\mathrm{g} \mathrm{kg}^{-1}\right)$ & 18.48 & Clay $\%$ & 38.3 \\
\hline Organic $N\left(\mathrm{~g} \mathrm{~kg}^{-1}\right)$ & 0.76 & Soil texture & Clay loam \\
\hline Organic $\mathrm{C} / \mathrm{N}$ ratio & 24.31 & & \\
\hline Mineral N (mg kg $\left.{ }^{-1}\right)$ & 58.46 & & \\
\hline Total $\mathrm{P}\left(\mathrm{g} \mathrm{kg}^{-1}\right)$ & 0.56 & & \\
\hline Available $\mathrm{P}\left(\mathrm{mg} \mathrm{kg}^{-1}\right)$ & 13.11 & & \\
\hline Total K $\left(\mathrm{g} \mathrm{kg}^{-1}\right)$ & 4.37 & & \\
\hline
\end{tabular}

\subsection{Experimental design}

Two field experiments were conducted at the Experimental Farm, Faculty of Agriculture, Minia University (latitude of $28^{\circ} 18^{\prime} 16^{\prime \prime} \mathrm{N}$ and longitude of $\left.30^{\circ} 34^{\prime} 38^{\prime \prime} \mathrm{E}\right)$, EL-Minia Governorate, Egypt, during two successive winter seasons of 2018/2019 and 2019/2020.

The scientific aim of this research was to assess the impacts of different combinations of chemical nitrogen fertilizer and red yeast as a biofertilizer i.e., $\left(\mathrm{F}_{1}, 100 \mathrm{~kg} \mathrm{~N}+\right.$ red yeast; $\mathrm{F}_{2}$, $75 \mathrm{~kg} \mathrm{~N}+$ red yeast; $\mathrm{F}_{3}, 50 \mathrm{~kg} \mathrm{~N}+$ red yeast; $\mathrm{F}_{4}$, $25 \mathrm{~kg} \mathrm{~N}+$ red yeast; $\mathrm{F}_{5}$, unfertilized $\mathrm{N}+$ red yeast; $\mathrm{F}_{6}, 100 \mathrm{~kg} \mathrm{~N}$ without red yeast), on microbial 
biomass $\mathrm{C}$ and $\mathrm{N}$, growth characters, yield, and its components as well as harvest index of four durum wheat cultivars $\left(\mathrm{V}_{1}\right.$, Beni-swif $5 ; \mathrm{V}_{2}$, Beni-swif 1; $\mathrm{V}_{3}$, Sohag4; $\mathrm{V}_{4}$, Sohag5). A randomized complete block design (RCBD) was used, in a split plot arrangement and replicated three times. Wheat cultivars were assigned to the main plots. The sub-plots were devoted to the fertilization system, each sub-plot area was 10.5 $\mathrm{m}^{2}(3.5 \times 3 \mathrm{~m})$, included 20 rows, $15 \mathrm{~cm}$ apart. The preceding crop was maize in both seasons, wheat grains were hand drilled in rows at the rate of 400 seeds $/ \mathrm{m}^{2}$. The mechanical and chemical analysis of the experimental soil was done before the sowing according to (Avery and Bascomb, 1982), as shown in Table 1 . The sowing dates were $20^{\text {th }}$ and $21^{\text {st }}$ of November in the first and second seasons, respectively. The harvesting was done on $25^{\text {th }}$ and $27^{\text {th }}$ of April in both seasons, respectively, Ammonium nitrate $(33.5 \% \mathrm{~N})$ as chemical $\mathrm{N}$ fertilizer was used, $\mathrm{N}$-fertilizer was splited into two doses, the first was applied 35 days after sowing (DAS), just before the $1^{\text {st }}$ irrigation, the second dose was applied 48 DAS. The amounts of the commercial fertilizer were calculated according to each nitrogen level in different fertilization system. Calcium superphosphate of $15.5 \% \mathrm{P}_{2} \mathrm{O}_{5}$ at the rate of $100 \mathrm{~kg} / \mathrm{fed}$ and potassium at the rate of $25 \mathrm{~kg}$ $\mathrm{K}_{2} \mathrm{O} /$ fed as potassium sulfate $\left(48 \% \quad \mathrm{~K}_{2} \mathrm{O}\right)$ were added at seed bed preparation. The treated plots were inoculated with Xanthophyllomyces dendrorhous Golubev (ATCC 96594): [VKM Y2793] supplied by American Type Culture Collection (ATCC) Manassas, VA 20108 USA of 35 days after sowing (DAS), just before the $1^{\text {st }}$ irrigation, the second dose was applied 48 DAS. The inoculants contained a minimum of $3 \times 10^{9}$ $\mathrm{mL}^{-1}$ viable cells (Moustafa et al., 2017).

\subsection{Microbial biomass $C$ and $N$ :}

Microbial biomass carbon $\left(\mathrm{C}_{\mathrm{mic}}\right)$ and nitrogen $\left(\mathrm{N}_{\text {mic }}\right)$ were determined on field moist samples using the chloroform fumigation-extraction procedure (Vance et al., 1987). In this technique, 5 $\mathrm{g}$ of each sampled soil was weighed into $50-\mathrm{mL}$ glass vials and fumigation was carried out for 24 hours at $25^{\circ} \mathrm{C}$. Extraction was thereafter made with $0.5 \mathrm{M}$ potassium sulfate solution $\left(\mathrm{K}_{2} \mathrm{SO}_{4} ; 5 \mathrm{~mL} \mathrm{~g}^{-1}\right.$ soil) and placed on a vacillating shaker for 30 minutes at $200 \mathrm{rev} \min ^{-1}$ and the suspension filtered through a Whatman 42 filter paper. Controls were not fumigated. An aliquot $(5 \mathrm{~mL})$ of each sample extract was then analyzed for $\mathrm{C}_{\text {mic }}$ as described by Vance et al. (1987), while $\mathrm{N}_{\text {mic }}$ was determined using the Kjeldahl digestion procedure (Brookes et al., 1985). $\mathrm{C}_{\text {mic }}$ and $\mathrm{N}_{\text {mic }}$ were then estimated by the differences between fumigated and unfumigated samples and dividing with $k$ factors of 0.45 for $\mathrm{C}_{\text {mic }}$ (Vance et al., 1987) and 0.54 for $\mathrm{N}_{\text {mic }}$ (Brooks et al., 1985).

\subsection{The recorded data}

At harvest, ten inner rows from each plot were harvested and ten plants were taken randomly to estimate the following data:

1- Plant height $(\mathrm{cm}$.): measured at harvest from soil surface to the tip of the spike of the main stem.

2- Number of tillers/plants.

3- Spike length $(\mathrm{cm}$.$) : measured at harvest from$ the main stems, which were used for estimation of plant height.

4- Number of spikelets/spikes: determined as number of fertile and sterile spikelets of ten spikes from each plot at harvest.

5- Number of grains /spikes: estimated on the basis of 10 spikes randomly collected from each plot.

6- 1000 grain weight (g.): determined from the three random samples each contained 1000 grains, taken from each plot, then the main of grain index was recorded.

7- Biological yield (ton/fed.): ten inner rows of $5.25 \mathrm{~m}^{2}$ of each plot harvested and weighted in $\mathrm{kg}$., then transformed into ton /fed.

8- Grain yield(ardab/fed.): according to harvested ten inner rows of $5.25 \mathrm{~m}^{2}$ of each plot in $\mathrm{kg}$., then transformed into ton /fed. 
9- Straw yield (ton /fed.): measured by subtracting grain yield (ton/fed.) from biological yield (ton/ fed.).

10- Harvest Index: was calculated using the following formula:

Harvest Index $=($ grain yield/biological yield $)$ $\times 100$.

\subsection{Statistical analysis}

All data were statistically analyzed according to technique of analysis of variance (ANOVA) for the split- plot design with three replications by means of "MSTAT-C" computer software package according to Gomez and Gomez (1984), and least significant differences (L.S.D.) test was used to compare treatment means at $5 \%$ level of probability.

\section{Results and Discussion}

\subsection{Effect of durum wheat cultivars on growth, yield, and its components}

3.1.1. Effect of durum wheat cultivars on growth characters

Data presented in Table (2) showed that durum wheat cultivars had a significant effect on No. of tillers/plant in the second season only. Beniswif1 $\left(\mathrm{v}_{2}\right)$ gave the highest value for this trait of 3.76 followed by Sohag4 ( $\left.v_{3}\right)$ of 3.63. This result may be due to the genetic behavior adaptation with environment conditions. These results are in agreement with those reported by (Hasanpour et al., 2012; Zaki et al., 2012; Yasser et al., 2018; Kasim et al., 2021).

\subsubsection{Effect of durum wheat cultivars on yield and its components characters}

Regarding the effect of durum wheat cultivars on yield and yield attributes characters, spike length (cm.), grain yield (ardab/fed.) and straw yield (ton/fed.) had highly significant affected in both seasons, as well as No. of spikelets/spike, No. of grains/spike and 1000 grain weight in the $1^{\text {st }}$ one. Moreover, cultivars differed highly significantly for biological yield (ton/fed.) in the $2^{\text {nd }}$ season, as shown in Table (2). Beni-swif $5\left(\mathrm{v}_{1}\right)$ surpassed all tested cultivars for spike length of 8.73 and $9.75 \mathrm{~cm}$. in the first and second seasons, respectively, and for No. of spikelets/spike of 17.09, No. of grains/spike of 50.48 and 1000 grain weight of 55.82 in the $1^{\text {st }}$ one, as well as biological yield of 5.65 ton/fed., grain yield of $15.95 \mathrm{ardab} / \mathrm{fed}$. and straw yield of $3.26 \mathrm{ton} / \mathrm{fed}$. in the second season, followed by Beni-swif $1\left(\mathrm{v}_{2}\right)$ for all previous traits. Meanwhile, Beni-swif $1\left(\mathrm{v}_{2}\right)$ recorded greatest grain yield of 17.53 ardab/fed., straw yield of 4.25 ton/fed. in the $1^{\text {st }}$ seasons. The differences among wheat cultivars under study could be attributed to the genetic make-up and their response to the environmental conditions prevailing during its growth. Similar trend of results was achieved by (Mohamed et al., 2013; Taher et al., 2013; Yasser et al., 2018; Bizuwork and Yibekal, 2020).

\subsection{Effect of different combinations of chemical nitrogen fertilizer and yeast biofertilizer on growth, yield and its components}

\subsubsection{Effect of chemical nitrogen fertilizer and yeast biofertilizer on growth characters}

The results involved in Table (3) revealed that nitrogen and bio-fertilization treatments possessed highly significant effect on growth characteristics i.e., plant height and No. of tillers/plant. $F_{1}$ recorded the highest values of no. of tillers/plant of 4.17 and 4.38 in the first and second seasons, respectively, as well as plant height of $101.04 \mathrm{~cm}$ in the $2^{\text {nd }}$ one, meanwhile the tallest plants of $103.85 \mathrm{~cm}$ were detected by $F_{3}$ in the first season. On contrary the lowest values for the previous growth traits were recorded by $F_{5}$. These results may be due to yeast as a bio fertilizer was not as effective as nitrogen chemical fertilizer on growth of wheat. High nitrogen demand of wheat needs readily available nutrient in peak-demanding stages, which improvement of growth and some yield 
attributes such as the spike length and 1000grain weight, which in turn increase in the grain yield/ plant, consequently grain yield/fad. This supports the findings of (El-Sirafy et al., 2006;
Metin et al., 2010; Ozturk et al., 2012; Namvar and Khandan, 2013; Rajasekaran et al., 2015; Yasser et al., 2018).

Table 2. Effect of durum wheat cultivars (Triticum durum L.) on growth yield, and its components at harvest in 2018/2019 and 2019/2020 seasons.

\begin{tabular}{|c|c|c|c|c|c|c|c|c|c|c|c|}
\hline \multicolumn{12}{|c|}{$2018 / 2019$} \\
\hline \multicolumn{2}{|c|}{$\begin{array}{l}\text { Characters } \\
\text { Treatments }\end{array}$} & $\begin{array}{l}\text { Plant } \\
\text { heigh } \\
\mathrm{t} \\
(\mathrm{cm} .)\end{array}$ & $\begin{array}{c}\text { No. of } \\
\text { tillers/plan } \\
t\end{array}$ & $\begin{array}{l}\text { Spike } \\
\text { lengt } \\
\mathrm{h} \\
(\mathrm{cm} .)\end{array}$ & $\begin{array}{c}\text { No. of } \\
\text { spikelet } \\
\text { s / } \\
\text { spike }\end{array}$ & $\begin{array}{c}\text { No. of } \\
\text { grains/spik } \\
\mathrm{e}\end{array}$ & $\begin{array}{l}1000 \\
\text { grain } \\
\text { weigh } \\
t(g)\end{array}$ & $\begin{array}{c}\text { Biologica } \\
1 \\
\text { Yield } \\
\text { (ton/fed.) }\end{array}$ & $\begin{array}{c}\text { Grain yield } \\
\text { (ardab/fed. } \\
\text { ) }\end{array}$ & $\begin{array}{c}\text { Straw } \\
\text { yield } \\
\text { (ton/fed. } \\
\text { ) }\end{array}$ & $\begin{array}{c}\text { Harves } \\
\mathrm{t} \\
\text { Index } \\
\%\end{array}$ \\
\hline \multirow{6}{*}{\multicolumn{2}{|c|}{ 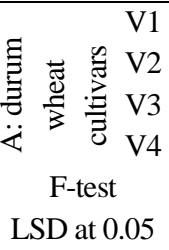 }} & 99.62 & 3.46 & 8.73 & 17.09 & 50.48 & 55.82 & 6.56 & 16.81 & 4.04 & 40.79 \\
\hline & & 99.75 & 3.48 & 8.64 & 16.40 & 48.45 & 55.09 & 6.88 & 17.53 & 4.25 & 40.53 \\
\hline & & 99.24 & 3.46 & 6.75 & 14.20 & 41.98 & 47.71 & 6.28 & 16.00 & 3.88 & 39.19 \\
\hline & & 99.54 & 3.48 & 6.32 & 14.77 & 43.59 & 48.08 & 5.67 & 14.38 & 3.52 & 39.78 \\
\hline & & NS & NS & $* *$ & $* *$ & $* *$ & $* *$ & NS & $* *$ & $* *$ & NS \\
\hline & & - & - & 0.94 & 0.01 & 0.10 & 2.93 & - & 0.25 & 0.04 & - \\
\hline \multicolumn{12}{|c|}{$2019 / 2020$} \\
\hline \multirow{4}{*}{ 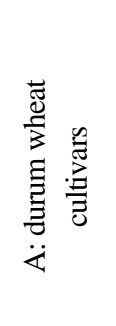 } & $\begin{array}{l}\mathrm{V} \\
1\end{array}$ & 93.64 & 3.62 & 9.75 & 17.05 & 50.71 & 58.41 & 5.65 & 15.95 & 3.26 & 42.40 \\
\hline & $\begin{array}{l}\mathrm{V} \\
2\end{array}$ & 94.12 & 3.76 & 9.12 & 16.90 & 47.22 & 58.58 & 5.59 & 15.82 & 3.22 & 42.67 \\
\hline & $\begin{array}{l}\mathrm{V} \\
3\end{array}$ & 93.95 & 3.63 & 7.75 & 14.17 & 45.94 & 53.49 & 5.44 & 15.45 & 3.12 & 42.71 \\
\hline & $\begin{array}{l}\mathrm{V} \\
4\end{array}$ & 94.10 & 3.56 & 6.67 & 13.50 & 43.70 & 48.43 & 5.03 & 14.38 & 2.88 & 4299 \\
\hline \multirow{2}{*}{\multicolumn{2}{|c|}{$\begin{array}{c}\text { F-test } \\
\text { LSD at } 0.05 \\
\mathrm{~V}:\end{array}$}} & NS & $*$ & $* *$ & NS & NS & NS & $* *$ & $* *$ & $* *$ & NS \\
\hline & & - & 0.11 & $\begin{array}{c}0.24 \\
\mathrm{~V} 1: \mathrm{Be}\end{array}$ & $\begin{array}{c}- \\
\text { i-swif } 5\end{array}$ & v2: Beni-sw & - & $\begin{array}{r}0.02 \\
\text { Sohag4 }\end{array}$ & $\begin{array}{c}0.24 \\
\text { v4: Sohag5 }\end{array}$ & 0.01 & - \\
\hline
\end{tabular}

\subsubsection{Effect of some chemical nitrogen fertilizer and yeast bio-fertilizer on yield and its components}

The impacts of different combinations of chemical nitrogen fertilizer and yeast bio-fertilizer on yield and its components were recorded in Table (3). All yield and its components i.e., spike length, No. of spikelets /spike, No. of grains/spike, 1000 grain weight, biological yield, grain yield, straw yield and harvest index were affected highly significant among different combinations of chemical $\mathrm{N}$ fertilizer and yeast bio-fertilization rates. $F_{1}$ was superior other than the fertilizer combinations for spike length (8.49 and 9.38 $\mathrm{cm}$.), 1000 grain weight $(55.09$ and $59.01 \mathrm{~g}$ ), biological yield (7.42 and 6.79ton/fed.), grain yield (19.51 and 18.92 ardab/fed.) and straw yield (4.50 and 3.95ton/fed.) in the first and second seasons respectively, and for No. of spikelets /spike of 17.19 and No. of grains/spike of 50.64 in the second season. While $F_{2}$ outperformed for No. of spikelets /spike of 17.09 and of No. grains/spike of 50.31 in the $1^{\text {st }}$ season. Meanwhile, the greatest harvest index values of $42.15 \%$ and $43.82 \%$ were obtained by $\mathrm{F}_{6}$ and $\mathrm{F}_{5}$ in the $1^{\text {st }}$ and $2^{\text {nd }}$ seasons, respectively. These results are in agreement with those reported by (El-Sirafy et al., 2006; Abd ElLateef, 2018; Manal et al., 2019; Bizuwork and Yibekal 2020; Kasim et al., 2021; Niel, 2021). Concerning the effect of yeast bio-fertilization alone on yield and its components, it could be concluded that the lowest values for all studied traits except harvest index were recorded by $\mathrm{F}_{5}$ and $\mathrm{F}_{6}$ bio-fertilizer combinations. In spite of $F_{1}$ 
was superior other than the fertilizer combinations for most studied traits, it could be concluded that $\mathrm{F}_{2}$ increased 1000 grain weight by 14.58 and $17.51 \%$; biological yield by 35.35 and $54.13 \%$; grain yield/plant by 45.69 and $48.10 \%$ and straw yield by 29.19 and $58.30 \%$ in the $1^{\text {st }}$ and $2^{\text {nd }}$ seasons, respectively as compared with $\mathrm{F}_{6}$ with no significant differences with $F_{1}$. Thus, $F_{2}$ surpassed the other nitrogen and bio-fertilization combinations for decreased total costs, pollution and maximized productivity and net profit per fed. This may be due to the role of bio-fertilization (red yeast application) in enhancement of physical and chemical soil properties and additional amount of nitrogen made available by biological fixation of nitrogen by organism, this nitrogen helps in improve growth and increase photosynthesis rate resulting in the accumulation of more dry matter by crop (Kasim et al., 2021; Niel, 2021). These results are in the same trend with those obtained by (Mostafa et al., 2017; Abd El-Lateef, 2018; Yasser et al., 2018).

Table 3. Effect of some chemical nitrogen fertilizer and yeast bio-fertilizer on growth yield, and yield component at harvest in 2018/2019 and 2019/2020 seasons.

\begin{tabular}{|c|c|c|c|c|c|c|c|c|c|c|c|}
\hline \multicolumn{12}{|c|}{$2018 / 2019$} \\
\hline \multicolumn{2}{|c|}{$\begin{array}{l}\text { Characters } \\
\text { Treatments }\end{array}$} & $\begin{array}{l}\text { Plant } \\
\text { height } \\
(\mathrm{cm} .)\end{array}$ & $\begin{array}{c}\text { No. } \\
\text { of } \\
\text { tiller } \\
\text { s/pla } \\
\text { nt }\end{array}$ & $\begin{array}{l}\text { Spike } \\
\text { length } \\
(\mathrm{cm} .)\end{array}$ & $\begin{array}{c}\text { No. of } \\
\text { spikelets/s } \\
\text { pike }\end{array}$ & $\begin{array}{l}\text { No. } \\
\text { of } \\
\text { grain } \\
\text { s/spi } \\
\text { ke }\end{array}$ & $\begin{array}{c}1000 \\
\text { grain } \\
\text { weight( } \\
\text { g.) }\end{array}$ & $\begin{array}{c}\text { Biological } \\
\text { Yield } \\
\text { (ton/fed.) }\end{array}$ & $\begin{array}{c}\text { Grain } \\
\text { yield } \\
\text { (ardab/fe } \\
\text { d.) }\end{array}$ & $\begin{array}{c}\text { Straw } \\
\text { yield } \\
\text { (ton/fed. } \\
\text { ) }\end{array}$ & $\begin{array}{l}\text { Harvest } \\
\text { Index } \%\end{array}$ \\
\hline \multirow{6}{*}{ 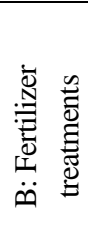 } & F1 & 102.34 & 4.17 & 8.49 & 16.59 & 48.92 & 55.09 & 7.42 & 19.51 & 4.50 & 39.91 \\
\hline & $\mathrm{F} 2$ & 103.18 & 3.76 & 8.29 & 17.06 & 50.31 & 54.70 & 7.39 & 19.42 & 4.47 & 37.91 \\
\hline & F3 & 103.85 & 3.66 & 8.08 & 16.75 & 49.32 & 53.81 & 7.06 & 18.41 & 4.30 & 38.26 \\
\hline & $\mathrm{F} 4$ & 100.64 & 3.35 & 7.31 & 15.03 & 44.53 & 50.64 & 5.94 & 14.63 & 3.75 & 42.02 \\
\hline & F5 & 91.78 & 2.52 & 6.49 & 14.14 & 41.89 & 48.06 & 4.82 & 11.78 & 3.05 & 40.17 \\
\hline & F6 & 95.45 & 3.34 & 6.99 & 14.10 & 41.78 & 47.74 & 5.46 & 13.33 & 3.46 & 42.15 \\
\hline \multicolumn{2}{|c|}{ F-test } & $* *$ & $* *$ & $* *$ & $* *$ & $* *$ & $* *$ & $* *$ & $* *$ & $* *$ & $* *$ \\
\hline \multicolumn{2}{|c|}{ LSD at0.05 } & 1.75 & 0.11 & 0.34 & 0.14 & 0.33 & 2.52 & 0.15 & 0.28 & 0.14 & 2.22 \\
\hline \multicolumn{12}{|c|}{$2019 / 2020$} \\
\hline \multirow{6}{*}{ 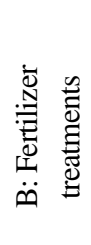 } & $\mathrm{F} 1$ & 101.04 & 4.38 & 9.38 & 17.19 & 50.64 & 59.01 & 6.79 & 18.92 & 3.95 & 41.74 \\
\hline & $\mathrm{F} 2$ & 99.60 & 4.04 & 9.19 & 16.91 & 49.60 & 58.85 & 6.72 & 18.75 & 3.91 & 41.77 \\
\hline & F3 & 95.99 & 4.26 & 8.83 & 16.40 & 49.89 & 55.02 & 5.94 & 16.76 & 3.43 & 42.20 \\
\hline & F4 & 90.89 & 3.00 & 7.86 & 14.53 & 46.12 & 54.02 & 4.72 & 13.53 & 2.69 & 43.06 \\
\hline & F5 & 85.43 & 2.86 & 7.28 & 13.48 & 41.53 & 51.39 & 4.04 & 11.79 & 2.27 & 43.82 \\
\hline & F6 & 90.76 & 3.33 & 7.39 & 13.91 & 43.57 & 50.08 & 4.36 & 12.66 & 2.47 & 43.57 \\
\hline \multicolumn{2}{|c|}{ F-test } & $* *$ & $* *$ & $* *$ & $* *$ & $* *$ & $* *$ & $* *$ & $* *$ & $* *$ & $* *$ \\
\hline \multicolumn{2}{|c|}{ LSD at 0.05} & 0.74 & 0.23 & 0.30 & 0.61 & 0.38 & 0.36 & 0.25 & 1. & 0.07 & 1.32 \\
\hline \multicolumn{2}{|c|}{$\mathrm{F}:$} & \multicolumn{10}{|c|}{$\begin{array}{c}\mathrm{F} 1=100 \mathrm{~kg} \mathrm{~N}+\text { red yeast, } \mathrm{f} 2=75 \mathrm{~kg} \mathrm{~N}+\text { red yeast, } \mathrm{f} 3=50 \mathrm{~kg} \mathrm{~N}+\text { red yeast, } \mathrm{f} 4=25 \mathrm{~kg} \mathrm{~N}+\text { red yeast, } \mathrm{f} 5= \\
\text { unfertilized } \mathrm{N}+\text { red yeast, } \mathrm{f} 6=100 \mathrm{~kg} \mathrm{~N} \text { without red yeast }\end{array}$} \\
\hline
\end{tabular}

3.3. Effect of the interaction between cultivars and different combinations of chemical nitrogen and yeast bio-fertilizer on growth, yield and yield component

3.3.1. Effect of the interaction between cultivars and different combinations of chemical nitrogen fertilizer and yeast bio-fertilizer on growth characters
Data presented in Tables (4 and 5) show the effect of interaction between cultivars and different chemical nitrogen fertilizer and yeast bio-fertilization combinations on growth, yield and yield component in the $1^{\text {st }}$ and $2^{\text {nd }}$ seasons. The presented data in Table (4) indicated that the interaction between durum wheat cultivars and different combinations of chemical nitrogen fertilizer and yeast bio-fertilizer did not show 
significant effect on plant height and No. of tillers/plant in both seasons. our findings are in conflicting with obtained by those, (Hassanein et al., 2018).

\subsubsection{Effect of the interaction between cultivars and some chemical nitrogen and yeast bio-fertilization combinations on yield and its components}

Influence of the interaction between durum cultivars and some nitrogen and bio-fertilization combinations was highly significant upon No. of grains/spike and biological yield in both seasons, spike length, No. of spikelets /spike and grain yield in the first season as well as, 1000 grain weight and straw yield in the second season, as shown in Tables (4 and 5). $\left(\mathrm{V}_{1 \times} \mathrm{F}_{1}\right)$ gave the tallest spike of $10.53 \mathrm{~cm}$., highest No. of spikelets/spike of 18.77 and No. of grains/spike of 55.33 in the $1^{\text {st }}$ season, however $\left(\mathrm{V}_{2} \times \mathrm{F}_{2}\right)$ recorded highest biological yield of 7.89 ton/fed., grain yield of $20.75 \mathrm{ardab} / \mathrm{fed}$. in the first season, 1000 grain weight of $61.66 \mathrm{~g}$. in the second season. Meanwhile, $\left(\mathrm{V}_{2} \times \mathrm{F}_{1}\right)$ surpassed all tested cultivar for biological yield of 7.40 ton/fed. and straw yield of 4.33 ton/fed. in the second season. The greatest No. of grain/spike of 55.63 was obtained by $\left(\mathrm{V}_{2} \times \mathrm{F}_{1}\right)$ in the second season. The finding results of (Hassanein et al., 2018) supported our findings.

Table 4. Effect of the interaction between cultivars and different combinations of chemical nitrogen and yeast bio-fertilizer on plant height, No. of tillers/plant, spike length, No. of spikelets/spike and No. of grains/spike at harvest in 2018/2019 and 2019/2020 seasons.

\begin{tabular}{|c|c|c|c|c|c|c|c|c|c|c|c|}
\hline \multirow{2}{*}{\multicolumn{2}{|c|}{$\begin{array}{l}\text { Characters } \\
\text { Treatments }\end{array}$}} & \multicolumn{2}{|c|}{ Plant height $(\mathrm{cm})}$. & \multicolumn{2}{|c|}{ No. of tillers/plant } & \multicolumn{2}{|c|}{ Spike length $(\mathrm{cm})}$. & \multicolumn{2}{|c|}{ No. of spikelets/spike } & \multicolumn{2}{|c|}{$\begin{array}{l}\text { No. of } \\
\text { grains/spike }\end{array}$} \\
\hline & & $1^{\text {st }}$ & $2^{\text {nd }}$ & $1^{\text {st }}$ & $2^{\text {nd }}$ & $1^{\text {st }}$ & $2^{\text {nd }}$ & $1^{\mathrm{st}}$ & $2^{\text {nd }}$ & $1^{\text {st }}$ & $2^{\text {nd }}$ \\
\hline \multirow{24}{*}{ 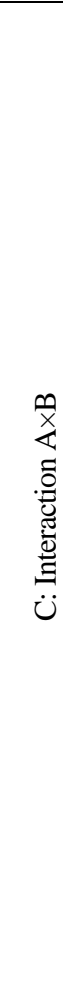 } & $\mathrm{V} 1 \times \mathrm{F} 1$ & 102.40 & 100.76 & 4.15 & 4.29 & 10.53 & 10.52 & 18.77 & 19.41 & 55.33 & 54.63 \\
\hline & $\mathrm{V} 1 \times \mathrm{F} 2$ & 103.13 & 99.63 & 3.76 & 3.80 & 10.36 & 10.55 & 18.00 & 18.82 & 53.06 & 52.56 \\
\hline & $\mathrm{V} 1 \times \mathrm{F} 3$ & 104.21 & 85.43 & 3.66 & 4.36 & 9.53 & 10.48 & 17.65 & 17.90 & 52.03 & 51.63 \\
\hline & $\mathrm{V} 1 \times \mathrm{F} 4$ & 100.62 & 90.40 & 3.35 & 3.16 & 7.65 & 9.36 & 15.79 & 16.41 & 46.76 & 48.90 \\
\hline & V1×F5 & 91.88 & 85.40 & 2.50 & 2.91 & 6.73 & 8.75 & 15.69 & 14.33 & 46.47 & 47.77 \\
\hline & V1×F6 & 95.50 & 90.24 & 3.34 & 3.22 & 7.56 & 8.83 & 16.62 & 15.43 & 49.21 & 48.77 \\
\hline & $\mathrm{V} 2 \times \mathrm{F} 1$ & 102.41 & 101.16 & 4.23 & 4.52 & 9.86 & 10.55 & 17.77 & 18.65 & 52.38 & 51.66 \\
\hline & $\mathrm{V} 2 \times \mathrm{F} 2$ & 103.41 & 99.89 & 3.76 & 4.21 & 9.16 & 10.05 & 17.60 & 18.57 & 51.88 & 49.56 \\
\hline & $\mathrm{V} 2 \times \mathrm{F} 3$ & 104.36 & 96.45 & 3.66 & 4.30 & 8.66 & 9.44 & 18.70 & 17.90 & 55.13 & 55.63 \\
\hline & $\mathrm{V} 2 \times \mathrm{F} 4$ & 100.27 & 91.06 & 3.36 & 3.04 & 8.53 & 8.72 & 16.19 & 15.64 & 47.94 & 46.81 \\
\hline & $\mathrm{V} 2 \times \mathrm{F} 5$ & 91.97 & 85.33 & 2.51 & 2.92 & 7.76 & 7.86 & 14.30 & 15.20 & 42.37 & 37.87 \\
\hline & $\mathrm{V} 2 \times \mathrm{F} 6$ & 96.06 & 90.81 & 3.35 & 3.58 & 7.86 & 8.07 & 13.84 & 15.44 & 41.01 & 41.83 \\
\hline & $\mathrm{V} 3 \times \mathrm{F} 1$ & 101.54 & 101.77 & 4.09 & 4.33 & 6.84 & 8.72 & 14.79 & 15.85 & 43.59 & 48.67 \\
\hline & $\mathrm{V} 3 \times \mathrm{F} 2$ & 102.96 & 98.69 & 3.76 & 4.20 & 7.10 & 8.48 & 15.90 & 15.75 & 46.87 & 48.78 \\
\hline & $\mathrm{V} 3 \times \mathrm{F} 3$ & 103.44 & 96.18 & 3.67 & 4.15 & 6.95 & 8.15 & 14.70 & 15.46 & 43.33 & 46.59 \\
\hline & $\mathrm{V} 3 \times \mathrm{F} 4$ & 101.19 & 91.14 & 3.36 & 2.99 & 6.93 & 7.56 & 13.56 & 13.42 & 40.18 & 44.87 \\
\hline & $\mathrm{V} 3 \times \mathrm{F} 5$ & 91.59 & 85.07 & 2.53 & 2.87 & 6.01 & 7.05 & 13.09 & 12.21 & 38.80 & 42.91 \\
\hline & $\mathrm{V} 3 \times \mathrm{F} 6$ & 94.70 & 90.84 & 3.36 & 3.26 & 6.65 & 6.56 & 13.19 & 12.34 & 39.09 & 43.87 \\
\hline & $\mathrm{V} 4 \times \mathrm{F} 1$ & 103.02 & 100.48 & 4.22 & 4.37 & 6.73 & 7.75 & 15.05 & 14.85 & 44.36 & 47.63 \\
\hline & $\mathrm{V} 4 \times \mathrm{F} 2$ & 103.22 & 100.20 & 3.77 & 3.94 & 6.53 & 7.68 & 16.77 & 14.52 & 49.43 & 47.53 \\
\hline & $\mathrm{V} 4 \times \mathrm{F} 3$ & 103.37 & 95.92 & 3.68 & 4.22 & 7.18 & 7.25 & 15.98 & 14.35 & 46.81 & 45.73 \\
\hline & $\mathrm{V} 4 \times \mathrm{F} 4$ & 100.46 & 90.94 & 3.34 & 2.83 & 6.12 & 5.79 & 14.59 & 12.64 & 43.22 & 43.91 \\
\hline & $\mathrm{V} 4 \times \mathrm{F} 5$ & 91.67 & 85.92 & 2.53 & 2.75 & 5.46 & 5.44 & 13.47 & 12.19 & 39.92 & 37.60 \\
\hline & $\mathrm{V} 4 \times \mathrm{F} 6$ & 95.53 & 91.13 & 3.36 & 3.25 & 5.89 & 6.09 & 12.76 & 12.44 & 37.82 & 39.81 \\
\hline \multicolumn{2}{|c|}{ F-test } & NS & NS & NS & NS & $* *$ & NS & $* *$ & NS & $* *$ & $* *$ \\
\hline \multicolumn{2}{|c|}{ LSD at 0.05} & - & - & - & - & 1.05 & - & 0.26 & - & 0.61 & 0.70 \\
\hline
\end{tabular}

Concerning the effect of interaction between cultivars and different combinations of chemical nitrogen and yeast bio-fertilizer, results in Tables (4 and5) indicated that $\left(\mathrm{V}_{4} \times \mathrm{F}_{5}\right)$ recorded the 
lowest values of spike length of $5.46 \mathrm{~cm}$. and grain yield of $10.80 \mathrm{ardab} / \mathrm{fed}$. in the $1^{\text {st }}$ season, No. of grains/spike of 37.60 and straw yield of
2.20 ton/fed. in the $2^{\text {nd }}$ season, as well as biological yield of 4.42 and 3.91ton/fed. in the $1^{\text {st }}$ and $2^{\text {nd }}$ seasons, respectively.

Table 5. Effect of the interaction between cultivars and different combinations of chemical nitrogen and yeast bio-fertilizer on 1000 grain weight, biological yield, grain yield, straw yield and harvest index at harvest in 2018/2019 and 2019/2020 seasons.

\begin{tabular}{|c|c|c|c|c|c|c|c|c|c|c|c|}
\hline \multicolumn{2}{|c|}{ Characters } & \multicolumn{2}{|c|}{1000 grain weight } & \multicolumn{2}{|c|}{ Biological Yield (ton/fed.) } & \multicolumn{2}{|c|}{$\begin{array}{l}\text { Grain yield } \\
\text { (ardab/fed.) }\end{array}$} & \multicolumn{2}{|c|}{ Straw yield (ton/fed.) } & \multicolumn{2}{|c|}{$\begin{array}{c}\text { Harvest } \\
\text { Index }\end{array}$} \\
\hline \multicolumn{2}{|c|}{ Treatments } & $1^{\text {st }}$ & $2^{\text {nd }}$ & $1^{\mathrm{st}}$ & $2^{\text {nd }}$ & $1^{\text {st }}$ & $2^{\text {nd }}$ & $1^{\mathrm{st}}$ & $2^{\text {nd }}$ & $1^{\text {st }}$ & $2^{\text {nd }}$ \\
\hline \multirow{25}{*}{ 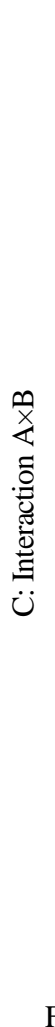 } & $\mathrm{V} 1 \times \mathrm{F} 1$ & 58.24 & 60.16 & 7.69 & 6.90 & 20.22 & 19.21 & 4.66 & 4.02 & 40.41 & 41.67 \\
\hline & $\mathrm{V} 1 \times \mathrm{F} 2$ & 57.51 & 59.09 & 7.86 & 7.00 & 20.67 & 19.47 & 4.76 & 4.08 & 38.12 & 41.62 \\
\hline & $\mathrm{V} 1 \times \mathrm{F} 3$ & 56.69 & 59.19 & 7.49 & 5.90 & 19.70 & 16.66 & 4.54 & 3.40 & 40.43 & 42.22 \\
\hline & $\mathrm{V} 1 \times \mathrm{F} 4$ & 55.01 & 57.11 & 6.09 & 5.12 & 15.33 & 14.32 & 3.79 & 2.98 & 43.15 & 41.94 \\
\hline & $\mathrm{V} 1 \times \mathrm{F} 5$ & 54.58 & 57.81 & 4.78 & 4.23 & 11.68 & 12.31 & 3.03 & 2.39 & 39.36 & 43.66 \\
\hline & $\mathrm{V} 1 \times \mathrm{F} 6$ & 52.86 & 57.11 & 5.42 & 4.76 & 13.24 & 13.74 & 3.43 & 2.70 & 43.27 & 43.29 \\
\hline & $\mathrm{V} 2 \times \mathrm{F} 1$ & 57.86 & 61.39 & 7.86 & 7.40 & 20.67 & 20.49 & 4.76 & 4.33 & 41.41 & 41.45 \\
\hline & $\mathrm{V} 2 \times \mathrm{F} 2$ & 57.86 & 61.66 & 7.89 & 7.27 & 20.75 & 20.16 & 4.78 & 4.25 & 39.45 & 41.50 \\
\hline & $\mathrm{V} 2 \times \mathrm{F} 3$ & 57.03 & 58.12 & 7.69 & 5.80 & 20.22 & 16.40 & 4.66 & 3.34 & 38.78 & 42.29 \\
\hline & $\mathrm{V} 2 \times \mathrm{F} 4$ & 56.21 & 58.14 & 6.19 & 5.03 & 15.13 & 14.46 & 3.92 & 2.87 & 42.06 & 43.13 \\
\hline & $\mathrm{V} 2 \times \mathrm{F} 5$ & 49.92 & 55.92 & 5.39 & 3.96 & 13.17 & 11.58 & 3.42 & 2.23 & 39.67 & 43.88 \\
\hline & $\mathrm{V} 2 \times \mathrm{F} 6$ & 51.68 & 56.24 & 6.23 & 4.06 & 15.22 & 11.85 & 3.95 & 2.29 & 41.80 & 43.80 \\
\hline & $\mathrm{V} 3 \times \mathrm{F} 1$ & 52.65 & 57.12 & 7.26 & 6.57 & 19.10 & 18.37 & 4.40 & 3.82 & 38.46 & 41.83 \\
\hline & $\mathrm{V} 3 \times \mathrm{F} 2$ & 50.43 & 58.36 & 7.19 & 6.40 & 18.91 & 17.93 & 4.36 & 3.71 & 38.07 & 41.92 \\
\hline & $\mathrm{V} 3 \times \mathrm{F} 3$ & 48.68 & 57.69 & 6.85 & 6.29 & 18.02 & 17.65 & 4.15 & 3.64 & 36.11 & 41.99 \\
\hline & $\mathrm{V} 3 \times \mathrm{F} 4$ & 46.06 & 54.83 & 6.09 & 4.76 & 14.88 & 13.74 & 3.86 & 2.70 & 41.39 & 43.29 \\
\hline & $\mathrm{V} 3 \times \mathrm{F} 5$ & 43.73 & 47.01 & 4.69 & 4.04 & 11.46 & 11.80 & 2.97 & 2.27 & 39.35 & 43.81 \\
\hline & $\mathrm{V} 3 \times \mathrm{F} 6$ & 44.73 & 45.95 & 5.59 & 4.56 & 13.66 & 13.20 & 3.54 & 2.58 & 41.75 & 43.42 \\
\hline & $\mathrm{V} 4 \times \mathrm{F} 1$ & 51.62 & 57.37 & 6.86 & 6.27 & 18.05 & 17.60 & 4.16 & 3.63 & 39.36 & 42.00 \\
\hline & $\mathrm{V} 4 \times \mathrm{F} 2$ & 53.00 & 56.29 & 6.59 & 6.20 & 17.34 & 17.42 & 3.99 & 3.59 & 36.01 & 42.04 \\
\hline & $\mathrm{V} 4 \times \mathrm{F} 3$ & 52.83 & 45.09 & 6.19 & 5.77 & 15.69 & 16.32 & 3.84 & 3.32 & 37.70 & 42.31 \\
\hline & $\mathrm{V} 4 \times \mathrm{F} 4$ & 45.29 & 46.01 & 5.39 & 3.97 & 13.17 & 11.61 & 3.42 & 2.23 & 41.49 & 43.88 \\
\hline & $\mathrm{V} 4 \times \mathrm{F} 5$ & 44.02 & 44.82 & 4.42 & 3.91 & 10.80 & 11.45 & 2.80 & 2.20 & 42.33 & 43.93 \\
\hline & $\mathrm{V} 4 \times \mathrm{F} 6$ & 41.70 & 41.04 & 4.59 & 4.06 & 11.21 & 11.85 & 2.91 & 2.29 & 41.79 & 43.80 \\
\hline & & NS & $* *$ & $* *$ & $* *$ & $* *$ & NS & NS & $* *$ & NS & NS \\
\hline
\end{tabular}

$\begin{array}{lllll}\text { LSD at } 0.05 & - & 0.67 & 0.30 & 0.47\end{array}$

These results may be due to the differences between four tested cultivars in growth custom and response of each cultivar to adapt with environmental conditions which was controlled by genetic factors and positively responded to nitrogen fertilizer. In addition, the bio-fertilizer with Xanthophyllomyces dendrorhous (red yeast) enhancing soil biological activity, which plays a significant role in regulating the dynamics of organic matter decomposition and the availability of plant nutrients and in increasing nitrogen fixer. These results are in good line with those mentioned by (Atia and Aly, 1998; Kader et al.,2002; Nawab et al.,2006; Bahrani and Pourreza,2010; Metin et al.,2010; Abd ElLattief,2016; Mostafa et al.,2017; Yasser et al.,2018).

\subsection{Effect on microbial biomass carbon and nitrogen}

Microbial biomass $\mathrm{C}$ and $\mathrm{N}$ are the most important biochemical pools that affect the $\mathrm{N}$ mineralization process in soils. They are considered as an indicator of the process of ammonification under different soil conditions (Haddad et al., 2013). Data presented in Table (6) show the effect of the combination of chemical nitrogen fertilizer levels and the red 
yeast on the microbial biomass $\mathrm{C}$ and $\mathrm{N}$ at two successive seasons. Generally, results confirmed that microbial biomass carbon $\left(\mathrm{C}_{\text {mic }}\right)$ significantly increased when using nitrogen fertilizer at $75 \%$ plus red yeast with Beni-swif 5 and 1 cultivar followed by using nitrogen fertilizer at $25 \%$ plus red yeast with the abovementioned cultivars. On the other hand, microbial biomass nitrogen $\left(\mathrm{N}_{\text {mic }}\right)$ significantly increased when using nitrogen fertilizer at $100 \%$ only without red yeast. This is maybe a result of the availability of nitrogen increased after inorganic $\mathrm{N}$ fertilizers additions and thus microorganisms immobilized $\mathrm{N}$ (Wang et al., 2008). Moreover, this is completely matched with the results obtained by Abd El-Azeim et al. (2020) who reported that, incorporated fertilization system recorded major levels of $\mathrm{N}_{\text {mic }}$ and $\mathrm{C}_{\mathrm{mic}}$ in comparison to inorganic fertilizers even though applied at lower rates. It is, accordingly, important for soils under any cropping system to balance organic and inorganic fertilizers that promote soil microbial activity and soil health.

Table 6. Effect of combination of chemical nitrogen fertilizer levels and the red yeast on the microbial biomass $\mathrm{C}$ and $\mathrm{N}$ at two successive seasons.

\begin{tabular}{|c|c|c|c|c|c|}
\hline \multirow{2}{*}{\multicolumn{2}{|c|}{ Cultivars/Treatments }} & \multicolumn{2}{|c|}{ Microbial biomass $\mathrm{C}(\mathrm{C}$ mic $)$} & \multicolumn{2}{|c|}{ Microbial biomass $\mathrm{N}(\mathrm{N}$ mic $)$} \\
\hline & & 2018/2019 & $2019 / 2020$ & $2018 / 2019$ & $2019 / 2020$ \\
\hline \multirow{6}{*}{ V1 } & F1 & 260 & 283 & 98 & 103 \\
\hline & $\mathrm{F} 2$ & 520 & 570 & 83 & 95 \\
\hline & F3 & 355 & 415 & 60 & 66 \\
\hline & $\mathrm{F} 4$ & 360 & 380 & 18 & 24 \\
\hline & F5 & 300 & 310 & 49 & 70 \\
\hline & F6 & 213 & 240 & 106 & 121 \\
\hline \multicolumn{2}{|c|}{ L.S.D 0.05} & 32.14 & 29.94 & 9.07 & 2.91 \\
\hline \multirow{6}{*}{$\mathrm{V} 2$} & F1 & 250 & 292 & 104 & 112 \\
\hline & $\mathrm{F} 2$ & 480 & 582 & 87 & 107 \\
\hline & F3 & 370 & 400 & 72 & 80 \\
\hline & $\mathrm{F} 4$ & 390 & 418 & 30 & 29 \\
\hline & F5 & 315 & 330 & 60 & 80 \\
\hline & F6 & 230 & 280 & 109 & 115 \\
\hline \multicolumn{2}{|c|}{ L.S.D 0.05} & 21.14 & 23.18 & 8.52 & 6.14 \\
\hline \multirow{6}{*}{ V3 } & F1 & 210 & 218 & 98 & 106 \\
\hline & $\mathrm{F} 2$ & 408 & 490 & 85 & 90 \\
\hline & F3 & 310 & 350 & 68 & 84 \\
\hline & $\mathrm{F} 4$ & 350 & 390 & 28 & 41 \\
\hline & F5 & 260 & 258 & 40 & 60 \\
\hline & F6 & 206 & 194 & 93 & 93 \\
\hline \multicolumn{2}{|c|}{ L.S.D 0.05} & 18.91 & 19.14 & 12.60 & 5.21 \\
\hline \multirow{6}{*}{ V4 } & $\mathrm{F} 1$ & 180 & 213 & 87 & 100 \\
\hline & $\mathrm{F} 2$ & 390 & 412 & 76 & 86 \\
\hline & F3 & 250 & 310 & 58 & 55 \\
\hline & $\mathrm{F} 4$ & 280 & 260 & 26 & 20 \\
\hline & F5 & 210 & 214 & 30 & 60 \\
\hline & F6 & 130 & 160 & 81 & 82 \\
\hline \multicolumn{2}{|c|}{ L.S.D 0.05} & 19.42 & 20.36 & 9.14 & 6.22 \\
\hline
\end{tabular}

\subsection{Statistical Correlation Analysis}

Grain yield in wheat is generally, determined by some growth characters viz, plant height, No. of tillers/plant and yield component characteristics viz, spike length, No. of spikelets/ spike, No. of grains/spike and 1000 grain weight. Adequate knowledge of the relationship that exists 
between grain yield and yield-related characteristics is essential for the identification of selection criteria to be used for yield improvement. Correlations coefficients among studied plant growth and yield quality characteristics were estimated during 2018 /2019 and 2019 /2020 seasons and presented in Table (6). The results revealed that grain yield (ardab/fed.) was highly significant and positively correlated with plant height ( $r=$ $.856^{* *}$ and $\left..860^{* *}\right)$, No. of tillers/plant $\left(r=.830^{* *}\right.$ and $\left..876^{* *}\right) \quad$, spike length $\left(\mathrm{r}=.740^{* *}\right.$ and $\left..712^{* *}\right)$, no. of spikelets / $\operatorname{spike}\left(r=.765^{* *}\right.$ and $\left..773^{* *}\right)$, no. of grains/spike(r=.758** and $.767 * *), 1000$ grain weight $(r=.739 * *$ and $.648 * *)$ and straw yield $(r=.9 .88 * *$ and $.999 * *)$ in the first and second seasons, respectively. The present findings are in agreement with that reported by (Fouad, 2018) who indicated that there was positive correlation between grain yield and each of number of spikes/plant and number of grains/spikes under different conditions. Waqar et al. (2010) declared that spike length, number of spikes per plant, number of spikelets per spike, number of grains per spike, number of tillers per $\mathrm{m}^{2}, 1000$ grain weight were significantly and positively correlated with grain yield per plant.

Table 7. Correlation between plant height, No. of tillers/plant, spike length, No. of spikelets / spike, no. of grains/spike and 1000 grain weight in addition to grain and straw yields/fed. at 2018/2019 and 2019/2020 seasons

$2018 / 2019$

\begin{tabular}{|c|c|c|c|c|c|c|c|c|}
\hline Correlation $\mathrm{r}$ value & $\begin{array}{c}\text { Plant } \\
\text { height } \\
\text { X1 }\end{array}$ & $\begin{array}{c}\text { No. of } \\
\text { tillers/plan } \\
\mathrm{t} \\
\mathrm{X} 2\end{array}$ & $\begin{array}{r}\text { Spike } \\
\text { length } \\
\text { X3 }\end{array}$ & $\begin{array}{l}\text { No. of } \\
\text { spikelets } \\
\text { / spike } \\
\text { X4 }\end{array}$ & $\begin{array}{c}\text { No. of } \\
\text { grains/spik } \\
\text { e } \\
\text { X5 }\end{array}$ & $\begin{array}{c}1000 \\
\text { grain } \\
\text { weight } \\
\text { X6 }\end{array}$ & $\begin{array}{c}\text { Grain } \\
\text { yield } \\
\text { Y }\end{array}$ & $\begin{array}{c}\text { Straw } \\
\text { yield } \\
\text { X7 }\end{array}$ \\
\hline Plant height & 1.00 & & & & & & & \\
\hline No.of tillers/plant & $.857 * *$ & 1.00 & & & & & & \\
\hline Spike length & $.498 *$ & $.487 *$ & 1.00 & & & & & \\
\hline $\begin{array}{c}\text { No. of spikelets / } \\
\text { spike }\end{array}$ & $.641 * *$ & $.542 * *$ & $.819 * *$ & 1.00 & & & & \\
\hline No. of grains/spik & $.631 * *$ & $.532 * *$ & $.821 * *$ & $1.000 * *$ & 1.00 & & & \\
\hline 1000 grain weight & $.560 * *$ & $.498 *$ & $.836^{* *}$ & $.907 * *$ & $.907 * *$ & 1.00 & & \\
\hline Grain yield & $.856^{* *}$ & $.830 * *$ & $.740^{* *}$ & $.765^{* *}$ & $.758 * *$ & $.739 * *$ & 1.00 & \\
\hline Straw yield & $.847 * *$ & $.818 * *$ & $.784 * *$ & $.757 * *$ & $.751^{* *}$ & $.757 * *$ & $.988 * *$ & 1.00 \\
\hline \multicolumn{9}{|c|}{$2019 / 2020$} \\
\hline Plant height & 1.00 & & & & & & & \\
\hline No.of tillers/plant & $.779 * *$ & 1.00 & & & & & & \\
\hline Spike length & $.405^{*}$ & $.584 * *$ & 1.00 & & & & & \\
\hline $\begin{array}{c}\text { No. of spikelets / } \\
\text { spike }\end{array}$ & $.532 * *$ & $.677 * *$ & $.949 * *$ & 1.00 & & & & \\
\hline No. of grains/spik & $.582 * *$ & $.676 * *$ & $.829 * *$ & $.805 * *$ & 1.00 & & & \\
\hline 1000 grain weight & $.424 *$ & $.511 *$ & $.869 * *$ & $.826 * *$ & $.694 * *$ & 1.00 & & \\
\hline Grain yield & $.860^{* *}$ & $.876^{* *}$ & $.712 * *$ & $.773 * *$ & $.767 * *$ & $.648 * *$ & 1.00 & \\
\hline Straw yield & $.859 * *$ & $.872 * *$ & $.717 * *$ & $.779 * *$ & $.766^{* *}$ & $.650 * *$ & $.999 * *$ & 1.00 \\
\hline
\end{tabular}

**Correlation is significant at the 0.01 level.

* Correlation is significant at the 0.05 level.

\section{Conclusion}

Good fertilization management is critical for the high yielding, quality, and profitability of different wheat cultivars. In Egypt, increasing wheat yield production by improving grain yield/fed should reduce the vast gap between wheat production and consumption. A better understanding of red yeast's role in the soil rhizosphere fertilized with chemical nitrogen 
fertilizer holds a key to sustainable agricultural practices in the future while minimizing environmental risks. Based on the above results, it could be included that dual application of $75 \%$ of the recommended chemical $\mathrm{N}$ fertilizer with red yeast Xanthophyllomyces dendrorhous on Beni-swif $(1,5)$ durum wheat cultivars had maximized wheat productivity and net profit per fed. as well as decreased total costs and pollution due to the reduction of chemical fertilizers used. Therefore, it can be recommended to replace nitrogen chemical fertilization by red yeast biofertilizer with $75 \%$ of the recommended chemical $\mathrm{N}$ to provide a high yield of Wheat while reducing the environmental pollution.

\section{References}

Abd El-Azeim, M.M., Sherif, M.A., Hussien, M.S., Haddad, S.A. (2020). 'Temporal impacts of different fertilization systems on soil health under arid conditions of potato monocropping.', J. Soil Sci. Plant Nutr., 20, pp. 322-334.

Abd El-Lattief, E.A. (2016). 'Response of wheat (Triticum aestivum, L.) to bio-organic fertilizers under southern Egypt conditions.', $3^{\text {rd }}$ Int. Conf. on Biotech. Appl. in Agric. (ICBAA), Benha Univ., Moshtohor and Sharm El-Sheikh, 5-9 April, Egypt.

Abd El - Lateef, A. A. (2018) ‘Effect of mineral and bio - fertilizers on productivity of wheat (Triticum aestivum L.) under Southwest Suez Canal Conditions. J. Plant Prod. Mansoura Univ., 9 (2), pp. 173 - 179

Abdul Galil, A.A., Basha, H.A., Mowafy, S.A.E., Mohamed, S.M. (2003). 'Effect of phosphorus addition on the response of four wheat cultivars to $\mathrm{N}$ fertilization level under sandy soil condition.', Minufiya J. Agric. Res., 28 (1), pp. 1-22.

Abou-Zeed, E.A.A., El-Salhy, A.M., AbdelGalil, H.A., Badawy, E.F.M. (2014). 'Effect of yeast and different phosphorus fertilizer sources on growth and fruiting of balady mandarin trees.', Assiut J. Agric. Sci., 45 (3), pp. 49-64.

Amal, M.A.A., Magda, G.A., Mohamed, H., Tawfik, M.M. (2011). 'Integrated effect of organic and biofertilizers on wheat productivity in new reclaimed sandy soil. Res. J. Agric. \& Biol. Sci., 7(1), pp. 105-114.

Amin, G.A., Geweifel, M.H.G., Gomaa, M.A., Nour, T.A. (2011). 'Effect of sowing method, micronutrients and nitrogen level on wheat yield under sandy soil conditions. Zagazig J. Agric. Res., 38 (2), pp. 233-248.

Amira, W.M.K., El-Khawaga, A.A.H., Saleh, M.E., Ramadan, I.E. (2016). 'Some biochemical nitrogen and phosphorus fertilization regimes impacts on wheat (Triticum aestivum L.) productivity. Zagazig J. Agric. Res., 43 (1), pp. 11-28.

Avery, B.W., Bascomb, C.L. (1982). 'Soil Survey Laboratory Methods.', Soil Survey Technical Monograph. (6), 83.

Bahrani, A.J., Pourreza, H.J.M. (2010). 'Response of winter wheat to co-inoculation with azotobacter and arbescular mycorrhizal fungi (AMF) under different sources of nitrogen fertilizer.', American-Eurasian J. of Agri.\& Envi. Sci., 8, pp. 95-103.

Bizuwork, T., Yibekal, A. (2020). 'Physiological Growth Indices of Durum Wheat (Triticum turgidum L. Var. durum) as Affected by Rates of Blended and Nitrogen Fertilizers.', American, J. of Life Sci., 8(4), pp. 52-59.

Brookes, P.C., Landman, A., Pruden, G., Jenkinson, D.S. (1985). 'Chloroform fumigation and release of soil $\mathrm{N}$ : A rapid direct extraction method to measure microbial biomass $\mathrm{N}$ in soil.', Soil Biol Biochem., 17, pp. 837-842. 
El-Sirafy, Z.M.; Woodward, H.J. and El-Norjar, E.M. (2006) ،Contribution of biofertilizer and fertilizer $\mathrm{N}$ to nutrient uptake and yield of Egyptian winter wheat. J Plant Nutr. 29(4):587-599.

FAO Statistics Division (2019). 'Food and Agriculture Organization of United Nations', Statistics Division.

Farag, I.A.A. and El-Khawaga, A.A.H. (2013) 'Influence of gamma irradiation and nitrogen fertilizer levels on Gammeza -9 wheat cultivar yield and its attributes. Arab J. Nuclear Sci. and Appl., 46 (2): 363-371.

Fouad, H.M. (2018) 'Correlation, Path and Regression Analysis in Some Bread Wheat (Triticum aestivum L.) Genotypes under Normal Irrigation and Drought Conditions. Egypt. J. Agron. 40(2): 133 - 144.

Gomez, K.A. and Gomez, A.A. (1984) 'Statistical Procedure for Agricultural research (2 ed.). John wiley and sons, NewYork.

Haddad, S. A.; Tabatabai, M.A. and Loynachan, T.E (2013) ‘Biochemical processes controlling soil nitrogen mineralization under waterlogged conditions. Soil Sci. Soc. Am. J. 77 (3) 809-816.

Hafez, E.M.M. (2007) ‘Effect of some agriculture practices on growth and productivity of wheat. M. Sc. Thesis Fac. Agric. Kafr El-Sheikh Univ., Egypt.

Hasanpour, J.; Panahi, M.; Arabsalmani, K. and Karimizadeh, M. (2012) 'Effects of late season water stress on seed quality and growth indices of durum wheat at different seed densities. Int. J. Agric. Sci., 2 (8): 702716.

Hassanein, M. S.; Amal, G. A. and Nabila, M. Z. (2018) 'Effect of nitrogen fertilizer and biofertilizer on yield and yield components of two wheat cultivars under sandy soil. Mid. E. J. of Appl. Sci., 8(1): 37-42.

Kader, M.A.; Miar, M.H. and Hoque, M.S. (2002) 'Effects of Azotobacter inoculants on the yield and Nitrogen uptake by Wheat. J. of Biol. Sci., 2(4): 259-261.

Metin, T. A.; Medine, G.B.; Ramazan, C.C.; Taskin, O.F.and Sahin, D. (2010) 'The effect of PGPR strain on wheat yield and quality parameters. Proceeding of World Congress of Soil Sci., Soil Solu. for a Changing World.1 6 August 2010, Brisbane, Australia.

Minaxi, J.S.; Chandra, S. and Nain, L. (2013) 'Synergistic effect of phosphate solubilizing rhizobacteria and arbuscular mycorrhiza on growth and yield of wheat plants. J. Soil Sci. and Plant Nut., 13 (2): 511-525.

Mohamed, A.Y.; Elsayed, M.M. and Sadek, I.I. (2013) 'Impact of organic manure, biofertilizer and irrigation intervals on wheat growth and grain yield. Ame. -Eurasian J. Agric. and Environ. Sci., 13(11): 1488-1496.

Mohamed, M. F.; Thalooth, A.T.; Tarek, A. E. and Ahmed, A. A. (2019) ،Yield and nutrient status of wheat plants (Triticum aestivum L.) as affected by sludge, compost, and biofertilizers under newly reclaimed soil. Bull. of the Nati. Res., Cen.43,31.

Moustafa, Y.M.M., Haddad S.A., Ahmed M.M.R. (2017) 'Influence of bio-fertilization with the red yeast (Phaffia rhodozyma) on growth, yield and inulin content of Jerusalem artichoke. Egypt J Exp. Biol (Bot.) 13(1):111-117.

Moustafa, Y.M.M., Hammam, A. A., Haddad, S. A. (2018) 'Potassium Humate Application and Cutting Immature Flowers affect Soil Properties, Microbial Activity and Jerusalem Artichoke Yield Components. Journal of Soil Sciences and Agricultural Engineering, 9(1), 33-41. 
Nabila, M. Zaki; Amal, G. Ahmed; Hassanein, M.S., and Mirvat, E. Gobarah, (2015) 'Response of two wheat cultivars to foliar fertilizer in newly cultivated land. Middle East J. Agric. Res., 4(2): 283-290.

Namvar, A. and Khandan, T. (2013) 'Response of wheat to mineral nitrogen fertilizer and biofertilizer (Azotobacter sp. And Azospirillum sp.) inoculation under different levels of weed interference. Ekologija, 59 (2): 85-94.

Nawab, K.; Amanullah, M. and Ali, A. (2006) 'Response of wheat to farmyard manure, potassium and zinc under rainfad cropping patterns. Middle East J. Sci. Res. 1(1): 1-9.

Niel, E. M. (2021) 'Effect of Organic and Nitrogen Fertilizers on Soil Fertility and Wheat Productivity in a Newly Reclaimed Sandy Soil. J. Alex. Sci. Exch.,42(3):573-582

Ozturk, A.; Bulut, S.; Yildiz, N. and Karaoglu, M.M. (2012) 'Effects of organic manures and non-chemical weed control on wheat: I Plant growth and grain yield. J. Agric. Sci., 18: 920.

Rajasekaran, S.; Sundaramoorthy, P. and Ganesh, K.S. (2015) 'Effect of FYM, N, P fertilizers and biofertilizers on germination and growth of paddy (Oryza sativa, L.). Int. Letters of Nat. Sci., 8: 59-65.

Singh, R. R. And Prasad, K. (2011) 'Effect of bio-fertilizers on growth and productivity of wheat (Triticum aestivum L.). J. of Farm Sci.1(1): 1-8.

Taher, E.B.; Faramarzi, A.; Ansari, M.H. and Rahmani, H.A. (2013) 'Study of the effects of the plant growth promoting bacteria on the yield and yield components of the wheat under the rain fad and irrigated conditions. Int. J. Agron. and Plant Prod., 4 (6): 13431350.

Vance, E.D., Brookes, P.C., Jenkinson, D.S. (1987) ، An extraction method for measuring soil microbial biomass C. Soil Biol. Biochem. 19, 703-707.

Wang, M. C., Liua, Y. H., Wang, Q., Gong, M., Hua, X. M, Pang, Y. J., Hu, S. and Yang, Y. H. (2008) ، Impacts of methamidophos on the biochemical, catabolic, and genetic characteristics of soil microbial communities. Soil Biology \&Biochemistry 40, 778-788.

Waqar, U. H.; Muhammad, M.; And Zahid A. (2010) 'Estimation of interrelationships among yield and yield related attributes in wheat lines. Pak. j. bot., 42(1): 567-573.

Yasser, A. M. Khalifa; Al-Aref, K.A.O.; Abd El-Lattief, E.A. and Youssif ,M.V. (2018) 'Influence of mineral, biological and organic nitrogen fertilizer regimes on two bread wheat cultivars under sandy soil conditions. Zagazig J. Agric. Res., 45 (6B):2269-2280.

Yigezu, A. Yigezu, Abbas, E.; Swelam, A.; Sabry S. R.S.; Moustafa, A. M and Halila, H. (2021) 'Socioeconomic, biophysical, and environmental impacts of raised beds in irrigated wheat: A case study from Egypt. Res. J. of Agricultural Water Management. (249):1-10.

Zaki, N. M.; Hassanein, M.S.; Amal, G. Ahmed; Ahmed, M.A. and Tawifk, M.M. (2016) 'Response of two wheat cultivars to different nitrogen sources in newly cultivated land. Res. J. of Pharmaceutical, Biolog. and Chem. Sci., 7 (6): 410-416. 